\title{
ACRL executive summary
}

Since June 1986, when the ACRL Board adopted the Strategic Plan developed by the Strategic Planning Task Force, the goals and objectives in the Plan have given us a way of looking at what we actually do in relation to what our members have said they wanted the Association to do.

The Plan has become, not just a paper document, but a lively guide reminding us of the directions ACRL members have given us. The major goals (professional development, capacitybuilding, advocacy, and research and publication) will probably not be accomplished within the plan's 5-year time frame. But specific objectives like "holding a national conference in 1989," will be.

Each month in this column I report to you ACRL's accomplishments, particularly in the goal areas of the Plan. As we move through the second year of the Plan, the Planning Committee will be formally soliciting from you the members, ideas for future directions. But even before you receive a formal invitation, please get in touch with them, to let them know where you want ACRL to move ahead in 1992, 1993, and after.

We have seen that a Plan can make a difference in how we place our emphasis and deploy our resources. Making the Plan is only half the fun. Carrying it out is really exciting.

For instance, in January at the Midwinter Meeting ACRL passed some important milestones.

\section{Goal I: Professional development}

Planning for the 5th ACRL National Conference in Cincinnati moved in exciting new directions:

- There will be programs as well as papers. The call for papers and programs is out; the deadline is

\section{Seats available on flights to Italy}

In conjunction with the WESS Florence Conference, ACRL has available group fare seating on regularly scheduled flights to Rome or Milan on April 2-3, 1988, from Los Angeles or New York. Return flights are on April 11, April 18, or later.

Travelers need not be registered for the WESS Conference in order to take advantage of the special fare.

The special fare from Los Angeles is $\$ 655$ and from New York it is $\$ 555$, for all those returning on April 11 or April 18. A $\$ 50$ surcharge applies for those returning after April 18. Anyone interested in an Italian trip next month may contact JoAn Segal at ACRL, (312) 944-6780.
July 31, 1988. See C $R L$ News, January 1988, p.4.

- There will be a 100th Birthday Party for academic library representation in ALA at the exhibits opening on Wednesday, April 5, 1989.

-A conference-wide event at the Public Library of Cincinnati and Hamilton County, on Friday night, April 7, will be included in the registration fee.

- A ticketed luncheon will highlight ACRL's contributions to academic librarianship over its 50year history. Guests will include past presidents and executive directors of ACRL.

\section{Goal II: Enhancing library service capability}

The Board agreed to contract with Nancy Van House to prepare a Manual for Output Measures. The ACRL staff was instructed to seek additional outside funding and to modify the 1989 budget to accommodate the expense. Expenditures in Fiscal Year 1988 have reduced ACRL's fund balance.

Further discussions were held with the National Endowment for the Humanities on possible funding for a proposal to involve Historically Black Colleges \& Universities (HBCU's) and their community public libraries in a project to provide good humanities programming for the public.

\section{Goal III: Advocacy and liaison}

The Board passed a resolution supporting the reauthorization of the Library Services and Construction Act.

\section{Strategic Management Directions}

Finances. The Board had previously decided to place in reserve an amount equal to half a year's average operating expenses. At the Midwinter Meeting they allocated $\$ 20,000$ in FY 1989 for a competitive Special Grants Fund and approved guidelines for applications and criteria for awards. This is specifically designed to put back into program activities funds the Board had been holding in reserve for various contingencies. Even after accruals and deferrals have been removed from fund balances, ACRL has a balance that exceeds the mandated reserve. The Board also voted to give $\$ 5,000$ to the Hugh Atkinson Memorial Award and to use $\$ 22,000$ toward the Output Measures Manual in the current fiscal year. These three decisions will reduce the fund balance, but the mandated reserve is still intact.

At the end of the first quarter, preliminary reports indicate that ACRL has received $22 \%$ of budgeted revenues and has spent $22 \%$ of budgeted expenses.

Staffing. Joe Boissé and JoAn Segal attended a seminar for chief elected and chief staff officers in 
San Francisco, January 21-22. The seminar stressed the nature of associations, roles and responsibilities of officers and staff, association infrastructure, and competencies for association management.

Membership. ACRL membership as of November 30, 1987, was 10,385 (down $1.5 \%$ from last year at the same time).

Leadership assistance. A leadership training session designed by ACRL President Joanne Euster involved the ACRL Board, key committee chairs, and staff for half a day on January 8 . Hosted by Richard Werking, director of the Trinity University Library and chair of ACRL's College Libraries Section, the session provided excellent material for orientation as well as for Board work. The facilitators were Board members themselves, and the results were obvious in the creative and cooperative problem-solving that Board members carried out during the Midwinter Meeting.
Board members and staff visited committees and section executive meetings to familiarize themselves with the work of many ACRL units.

ALA cooperation. Before and during the Midwinter Meeting, the ACRL Executive Director participated heavily in preparing ALA planning materials and the Financial Seminar on January 8.

At the meeting the ACRL Board spent 90 minutes reviewing the ALA planning materials; President Euster will send a report of that review to Bill de John, chair of the ALA Planning Committee.

You will be pleased to learn that Sharon Hogan has been elected to the ALA Executive Board for a four-year term beginning this July. That makes 2 ACRL Past Presidents on the ALA governing body (Carla Stoffle is the other) and gives academic librarians as well as those interested in divisions in general another Board representative. $-J o A n S$. Segal, ACRL Executive Director.

\section{Guidelines/criteria for special grant funds}

The following guidelines/criteria were passed by the ACRL Board at the January 1988 Midwinter Meeting in San Antonio.

Grant proposals may be submitted by any section, chapter, or committee of ACRL. However, each ACRL unit can participate in submitting only one (1) proposal in each funding period.

\section{Grant proposals shall:}

1. Be consistent with the ACRL Strategic Plan and Priorities identified by the ACRL Board for any given year.

2. Be used to fund only one-time projects. Funds cannot be used for ongoing projects.

3 . Not be used to fund ongoing or routine operating costs, e.g., newsletters, annual directories, etc.

4. Promote ACRL visibility.

5. Stimulate ACRL membership.

6 . Not be used for re-grant purposes or for redistribution to other recipients; e.g., Chapters Council cannot get a grant to enlarge a pool of money available for chapters competition.

\section{Preferences for ranking:}

1. Projects which demonstrate wide impact on membership.

2. Unique and innovative projects.

3. Complete, concise, well-developed proposals.

Bear in mind, the Review/Rating Committee (not in priority order):

1. Will consider impact of proposal on ACRL Headquarters staff.

2. Is not obligated, nor is the ACRL Board, to fund proposals in their entirety.

3. Neither encourages nor discourages joint proposals.
4. Encourages proposal writers to be complete, yet concise, in explaining their projects.

5. Requires four (4) copies of each proposal to be at ACRL Headquarters by the deadline (N.B.: FY1989 proposals must be received at ACRL Headquarters by June 1, 1988).

6 . Requires all proposals to have a fiscal administrator.

7. Insists that all funds be expended according to existing ACRL policies and procedures.

\section{Document delivery papers needed}

The International Federation of Library Associations and Institutions' Office for International Lending, in cooperation with the journal Interlending and Document Supply, is planning an international conference on all aspects of document delivery to be held November 14-16, 1988, in the Connaught Rooms in the London city center.

Many different aspects of document delivery will be covered, including electronic document delivery, union catalogs, conservation, access to materials causing particular problems, copyright, and the support of document delivery by reference services.

Anyone interested in making a presentation to the 150 or so delegates expected may contact: Graham P. Cornish, Assistant to the Director, IFLA Office for International Lending, c/o The British Library Document Supply Centre, Boston Spa, Wetherby, West Yorkshire LS23 7BQ, United Kingdom. 
NOW... Your Library Can Have aris

To provide the utmost in service, you know that F every helpful librarian needs a quick, easy resource of worldwide serials with a top-notch user guide

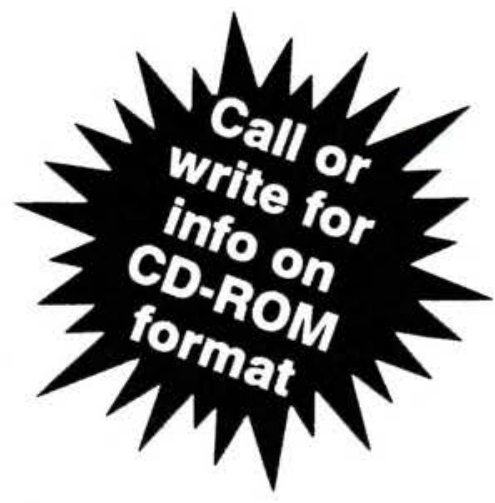
GEt . . . from EBSCO... in the superior serials reference:

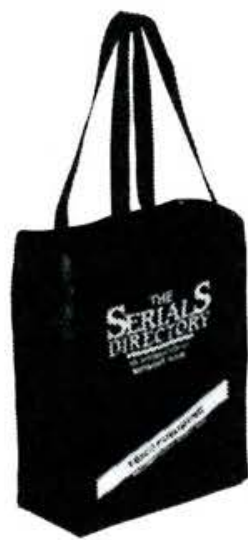

\section{SEE What Your Library May Be Missing:}

Number of titles listed

Includes both annuals and

irregular series along with

other type serials in one book

Includes titles worldwide

Includes authenticated MARC

record and CONSER file data

Includes CONSER control numbers

Has separate "Ceased Title"

Index of over 5,000 periodicals

Includes LC classifications

Includes NLM classifications

Includes UDC classifications

Includes CODEN designations

Number of volumes in set

Number of pages in set

Publishers price

Ulich's publishes one book for periodicals, another for annuals and irregular serials. Although the two for fair comparison. If purchased separately, price would be $\$ 39490$.

\section{Included Free!...USER GUIDE:}

No major reference book ever was easier to use. A clearly-written User Guide-explaining sample listings, showing how to find entries quickly-enables anyone to get maximum help from this landmark Directory.

\section{YOUR MONEY-BACK GUARANTEE}

- EBSCO invites you to examine THE SERIALS DIRECTORY on your own premises, for one full month.

- If, at any time during the first month of your review of these mammoth volumes, you decide for any reason whatever not to keep them, just return the books undamaged. Your payment of $\$ 289.00$, which includes $\$ 10.00$ shipping/handling/insurance, will be immediately refunded...no questions asked.

- This Unconditional Guarantee is backed by EBSCO, a dependable company known to libraries worldwide, publishers of the famous Librarians' Handbook. Guarantee Authorized by:

$$
\text { Joe K. Weed, Vice President }
$$

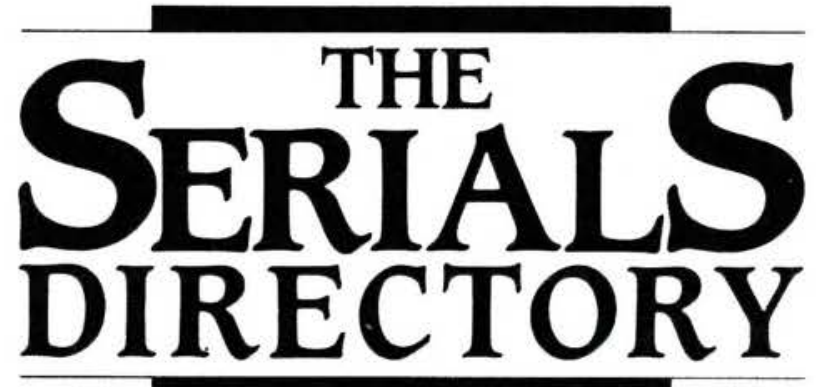

AN INTERNATIONAL REFERENCE BOOK

"In the comparison that counts the most, during the time the EBSCO directory was under review, it was able to, answer several reference questions Ulrich's failed on " Wilson Library Bulletin

February 1987

"Entries in the Directory contain more information than the Bowker alternatives, with up to thirty-seven separate elements for each title. The Dewey numbers assigned in the EBSCO entries are more complete and in addition LC. UDC, NLM and CODEN numbers are included.'

Australian Academic \& Research Libraries, March 1987

" "...we like The Serials Directory so much we would like to be placed on Standing Order.

Pauline S. Thrash, Technical Service Assistant University of North Carolina-Asheville PUT this usefulness at your fingertips!

Call or write today to immediately get your Inspection copy!

\section{YOU GET ALL THIS:}

- 114,000 serials-more than ANY other directory

- up to 38 separate pieces of data on each title

- Library of Congress. Dewey Decimal National Library of Medicine

- Universal Decimal Classifications

- CODEN designations

- the ONLY listing of over 5,000 ceased titles by both alphabetical index and by subject heading

- complete listing of indexes and abstracts for each title when available

Call Now, Toll-Free, Risk-Free

\section{1-800-826-3024}

for your reservation copy

Published by EBSCO Publishing

Box 1943, Birmingham, AL 35201

Publication date for print version is September 1987. CD-ROM avalable Winter free tote vantage of this offer TODAY -Call Toll-Free 1-800-826-3024

NOW... Get THE MOST COMPLETE INTERNATIONAL DIRECTORY and REFERENCE BOOK OF SERIALS Ever PUBLISHED 